

Tersedia online di: http://ejournal-balitbang.kkp.go.id/index.php/jppi

JURNAL PENELITIANPERIKANANINDONESIA

Volume 24 Nomor 1 Maret 2018

p-ISSN: 0853-5884

e-ISSN: 2502-6542

Nomor Akreditasi: 653/AU3/P2MI-LIPI/07/2015

\title{
UJI COBA PENANGKAPAN JARING INSANG DUA LAPIS UNTUK MENANGKAP IKAN TERUBUK (Tenualosa macrura Bleeker, 1852) HIDUP DI BENGKALIS
}

\section{EXPERIMENTAL FISHING OF DOUBLE GILL NET FOR CATCHING LIFE TERUBOK (Tenualosa macrura Bleeker, 1852) AT BENGKALIS}

\author{
Hufiadi $^{* 1}$ Mahiswara ${ }^{1}$ dan Baihaqi ${ }^{1}$ \\ ${ }^{1}$ Balai Riset Perikanan Laut, Kompl. Raiser JI. Raya Bogor KM. 47, Cibinong, Bogor, Jawa Barat Indonesia \\ Teregistrasi I tanggal: 20 Desember 2016; Diterima setelah perbaikan tanggal: 05 Februari 2018; \\ Disetujui terbit tanggal: 12 Februari 2018
}

\begin{abstract}
ABSTRAK
Ikan terubuk (Tenualosa macrura Bleeker, 1852) merupakan komoditas perikanan yang penting di Bengkalis, Provinsi Riau. Populasi terubuk di Bengkalis sangat menurun akibat dieksploitasi meskipun pembatasan penangkapan juga telah diterapkan melalui metode konservasi. Upaya selain konservasi juga melalui budidaya ikan namun upaya ini terkendala oleh ketersedian ikan terubuk hidup baik sebagai induk maupun ikan dewasa. Tulisan ini membahas hasil uji coba pengoperasian alat penangkap ikan jaring dua lapis untuk menangkap ikan terubuk hidup. Uji coba penangkapan dilaksanakan pada tahun 2015 - 2016 di perairan Selat Bengkalis dan sekitarnya. Hasil uji coba penangkapan menunjukkan bahwa jenis ikan yang dominan tertangkap adalah ikan biang-biang (Setipinna breviceps) dan nomei (Harpodon sp). Laju tangkap jaring dua lapis terhadap ikan terubuk berkisar 0,7 - 2,6 ekor/setting. Jumlah ikan terubuk yang tertangkap dalam kondisi hidup mencapai $27,1 \%$ dari total tangkapan ikan terubuk. Nilai ukuran panjang pertama kali tertangkap ikan terubuk dengan jaring dua lapis $\left(L_{c}\right)$ yaitu 17,43 cmFL.
\end{abstract}

Kata Kunci: Jaring dua lapis; terubuk; uji coba penangkapan; Bengkalis

\begin{abstract}
Terubok (Tenualosa macrura Bleeker, 1852) is an important fish commodity in Bengkalis, Riau Province. The terubok resosurce in Bengkalis is heavily degraded due to the high exploitation even fishing limitation was applied in term of species conservation. Conservation efforts through fishculture are constrained by the availability of live terobuk fish as both parent and adult fish. This paper present the results of fishing trial of double-net fishing gear for catching alive terubok fish. Fishing trial was conducted in 2015-2016 periods in Bengkalis strait waters and its adjascent. The results shown that the dominant fish catches of doublé net were Shorthead hairfin anchovy (Setipinna breviceps) and bombay duck (Harpodon sp). Double gill net catch rate for terubok were between $0,7-2,6$ fish/setting. Number of alive terubok fish was $27,1 \%$ of total terubok catches, length of first capture $\left(L_{c}\right)$ value of terubok by using doublé net was $17.4 \mathrm{~cm} \mathrm{FL}$.
\end{abstract}

Keyword: Double net; terubok; trial fishing; Bengkalis

\section{PENDAHULUAN}

Di Indonesia ikan terubuk diketahui hanya ditemukan di pantai timur Sumatera, antara lain jenis Tenualosa macrura di perairan estuarin di Kabupaten Bengkalis Provinsi Riau, Tenualosa ilisha di perairan Labuhan Batu dan Labuhan Bilik (Sumatera Utara), sedangkan Tenualosa toli ditemukan di perairan estuarin Serawak (Blaber et al., 1996). Ikan terubuk (Tenualosa spp.) adalah jenis ikan yang hidup di perairan estuarin, bersifat 'protandrous hermaphrodite' dan endemic. Ikan terubuk (Tenualosa macrura) adalah spesies ikan endemik di perairan Bengkalis, Provinsi Riau. Populasi terubuk di Bengkalis sudah sangat 
menurun akibat eksploitasi yang tinggi dan telah terjadi recruitment overfishing meskipun telah dilakukan pembatasan penangkapan melalui peraturan 'perlindungan terbatas' dan konservasi jenis (Suwarso, 2016).

Ikan terubuk merupakan sumberdaya ikan yang memiliki nilai ekonomis tinggi dan menjadi primadona di seluruh wilayah Provinsi Riau. Carpenter \& Niem (1999), menerangkan bahwa ikan terubuk merupakan ikan pelagis yang termasuk dalam Famili Clupeidae, yang bersifat berganti kelamin (hermaprodit proandri) dan menjalani siklus hidup dalam waktu kurang dari dua tahun (sekitar 18 bulan). Pada tahun pertama kehidupannya akan dilalui sebagai ikan jantan (disebut "pias") dan pada tahun kedua akan berganti kelamin menjadi ikan betina sebagai "terubuk" (Blaber et al., 1991). Pada tahap larva dan juvenil ikan terubuk bermigrasi menuju perairan Sungai Siak yang memiliki salinitas lebih rendah (Blaber, 1998).

Berdasarkan hasil pengamatan dan wawancara dengan nelayan, di perairan Kabupaten Bengkalis dan Kepulauan Meranti kegiatan penangkapan ikan terubuk dilakukan hampir sepanjang tahun dengan menggunakan alat penangkap ikan jaring insang (gill net). Selama ini, jaring insang dioperasikan di jalur migrasi induk-induk ikan terubuk yang melakukan ruaya untuk keperluan memijah. Bila yang tertangkap adalah ikan yang belum sempat memijah, maka aktivitas penangkapan ikan ini secara langsung akan mengancam kelangsungan dan kelestarian sumberdaya ikan terubuk.

Kecenderungan menangkap ikan yang kurang mempertimbangkan aspek keberlanjutan sumberdaya telah dirasakan dampaknya oleh nelayan setempat. Sejak tahun 1970-an, gejala menurunnya populasi ikan terubuk di perairan Riau sudah terjadi (Ahmad, 1974) dan pada awal tahun 1980-an ikan hanya dijumpai dalam jumlah yang amat sedikit di perairan Tanjung Medang, padahal perairan ini merupakan sentra produksi ikan terubuk sebelumnya (Ahmad, 1975). Produksi ikan terubuk di Bengkalis hanya berkisar antara 0,5 - 10 ton/tahun (Suwarso \& Merta, 1997). Penangkapan yang dilakukan secara berlebihan dan terjadinya kerusakan lingkungan diduga telah menyebabkan penurunan populasi ikan terubuk secara drastis (Merta et. al, 1999).

Berbagai upaya telah dilakukan oleh pemerintah pusat maupun daerah untuk menjaga agar populasi ikan terubuk tidak mengalami kepunahan. Salah satu yang dilakukan adalah melalui kegiatan usaha budidaya. Namun, upaya ini terkendala oleh sulitnya memperoleh ikan indukan, yang sepenuhnya berasal dari alam. Induk ikan terubuk untuk keperluan budidaya yang telah diupayakan, kurang memenuhi syarat, akibat kondisi stress dan luka secara fisik sejak dari proses penangkapan dengan alat jaring insang (gill net) seperti digunakan nelayan selama ini.

Sampai saat ini jaring insang yang dioperasikan oleh nelayan Bengkalis, Sei Pakning dan Kepulauan Meranti umumnya memiliki ukuran mata jaring (mesh size) antara 2,0 - 3,0 inci. Pengunaan jaring insang, menjadikan ikan yang tertangkap umumnya terjerat pada bagian insangnya (Baskoro, 2006; Subani \& Barus, 1989), sehingga tidak jarang ikan tangkapan dalam kondisi cedera, luka dan stress, yang akhirnya dapat menyebabkan kematian.

Untuk dapat memperoleh induk ikan terubuk yang sesuai kebutuhan budidaya perlu dicari alternatif jenis alat penangkap ikan dan cara penangkapan yang mampu menjamin hasil tangkapan ikan terubuk dalam kondisi sehat; tidak terluka, sedikit mungkin mengalami stress, mampu meningkatkan kelulusan hidupnya. Dalam rangka mendukung upaya budidaya ikan terubuk, telah dilakukan perancangan, pengkonstruksian dan uji coba pengoperasian alat penangkap ikan jaring dua lapis untuk menangkap induk ikan terubuk hidup. Penelitian uji coba pengoperasian jaring dua lapis telah dilaksanakan di perairan Bengkalis, dimana merupakan hábitat spesies endemik ikan terubuk. Paper ini menyajikan bagaimana kinerja jaring dua lapis dalam menangkap ikan terubuk dalam kondisi hidup melalui uji coba penangkapan. Komposisi hasil tangkapannya, laju tangkap terhadap ikan terubuk serta ukuran ikan terubuk yang tertangkap juga disampikan dalam tulisan ini.

\section{BAHAN DAN METODE Lokasi dan Waktu Penelitian}

Penelitian dilakukan pada Mei dan November 2015 dan Mei, September, dan Oktober 2016. Lokasi penelitian di wilayah perairan Kabupaten Bengkalis, Provinsi Riau, dengan posisi 01018"301'S $01^{\circ} 21^{\prime \prime} 538^{\prime} S$ s/d 102¹0"822'E - 103¹2"182'E (Gambar 1).

\section{Rancang Bangun Jaring Insang Dua Lapis}

Jaring insang dua lapis (termasuk kategori jaring insang) konstruksinya terdiri atas 2 (dua) lembar bahan jaring (webbing) berbahan polyamida (PA) monofilament, yang masing masing memiliki ukuran/ nomor benang dan mata jaring yang berbeda. Lembar/ lapis jaring pertama (dalam/inner) menggunakan 
benang PA monofilament No. 0,20 dengan ukuran mata jaring $1 \frac{1}{2}$ inci dan jaring kedua (luar/outer) berbahan PA monofilament No. 0,60 dengan ukuran mata jaring lebih besar yaitu 7 inci. Untuk keperluan perakitan, terhadap jaring pertama dan kedua diberikan nilai koefisien pengikatan (hanging coeffecient) sebesar 0,40 dan 0,70. Dengan nilai koefesien pengikatan tersebut 1 pis jaring dua lapis memiliki ukuran panjang terpasang $32 \mathrm{~m}$ dan tinggi jaring 5,3 m (Gambar 2).


Gambar 1. Lokasi uji penangkapan terubuk dengan jaring insang dua lapis.

Figure 1. Location of trial fishing for catching terobok using double gill net.

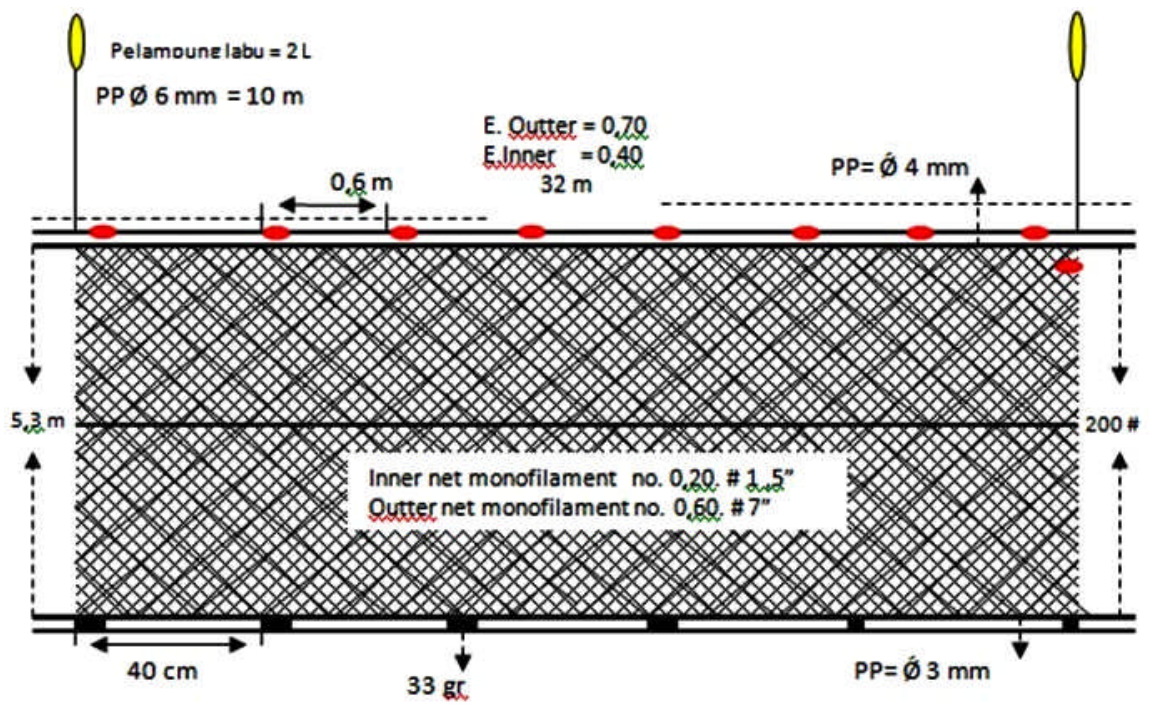

Gambar 2. Desain jaring insang dua lapis yang diuji coba untuk penangkapan terubuk.

Figure 2. Desaign of double gill net for trial fishing for catching terobok.

Jumlah jaring insang dua lapis yang dioperasikan selama kegiatan uji coba penangkapan sebanyak 22 pis dalam setiap kali operasi penangkapan (setting).

\section{Pengumpulan Data}

Data dan informasi untuk keperluan analisis kinerja jaring insang dua lapis untuk mendapatkan hasil tangkapan ikan terubuk hidup, diperoleh melalui uji coba pengoperasian (fishing trial). Pengoperasian jaring dua lapis dilakukan dengan menggunakan kapal berukuran 5 GT milik nelayan. Jaring insang dua lapis dioperasikan dengan cara dihanyutkan di kolom perairan pada kedalaman antara 8-16 $\mathrm{m}$ di bawah permukaan air. Tebar (Setting) jaring insang dua lapis memerlukan waktu antara 10-15 menit, waktu rendam (soaking time) antara 10-30 menit dan waktu pengangkatan (hauling time) berkisar antara 40-80 menit. Data yang dihimpun selama kegiatan uji coba pengoperasian meliputi; hasil tangkapan (jenis ikan, ukuran ikan, kondisi pasca penangkapan), operasional penangkapan (posisi, setting time, hauling time, soaking time), serta data kondisi perairan (kedalaman, kecerahan, tipe dasar perairan). Proses penangkapan dan penanganan hasil tangkapan ikan terubuk di atas kapal disajikan pada Gambar 3. 
Terhadap ikan terubuk yang tertangkap dalam kondisi masih hidup, dilakukan penanganan khusus selama kegiatan operasi penangkapan, agar ikan masih mampu bertahan hidup. Bak ber-aerator digunakan sebagai wadah untuk menampung dan mempertahankan ikan terubuk hidup. Durasi ketahanan hidup mulai saat dilepaskan dari jaring insang dan selama dalam bak ber-aerator menjadi data kondisi ikan terubuk hidup.


Gambar 3. Pengoperasian jaring insang dua lapis dan posisi ikan tertangkap.

Figure 3. Fishing operation of double gill net and position of fish caught.

\section{Analisis Data Komposisi Hasil Tangkapan}

Identifikasi jenis ikan terubuk dan hasil tangkapan lainnya mengacu pada buku identifikasi Bruin et al. (1994). Komposisi hasil tangkapan dihitung berdasarkan persentase (\%) jumlah individu untuk masing-masing jenis ikan yang tertangkap. Persentase hasil tangkapan ditentukan baik terhadap terhadap ikan terubuk maupun hasil tangkapan lainnya. Disamping jumlah individu hasil tangkapan, terhadap ikan terubuk yang tertangkap juga dicatat kondisi ikan saat tertangkap serta pengamatan durasi daya hidup pasca penangkapan.

\section{Laju Tangkap}

Data laju tangkap jaring insang dua lapis dihitung berdasarkan hasil tangkapan (catch) per-tawur (setting) sebagai upaya penangkapan yang lebih dikenal sebagai CPUE (Catch per Unit Effort). Penghitungan nilai rataan laju tangkap menggunakan formula:

$$
\text { Laju Tangkap }=\frac{\text { Catch }}{\text { Setting }}
$$

dimana;

Catch $=$ Jumlah hasil tangkapan (ekor)

Setting $=$ Jumlah tawur (kali setting)

\section{Ukuran Ikan Tertangkap}

Informasi biometric ikan diperoleh melalui pengukuran panjang cagak (FL), panjang total (TL) dan berat (W) ikan hasil tangkapan. Data ukuran ikan hasil tangkapan ditabulasi per individu ikan. Data digunakan untuk menghitung parameter ukuran ratarata tertangkap. Kinerja jaring insang terhadap ukuran ikan yang tertangkap, dianalisis melalui pendugaan ukuran ikan pertama kali tertangkap (Length at first capture $=L c$ ). Ukuran ikan pertama kali tertangkap $\left(L_{c}\right)$ merupakan $50 \%$ fraksi tertahan (ikan yang tertangkap $=\mathrm{L}_{50 \%}$ ) dari alat tangkap yang digunakan. Nilai $L_{c}$ diperoleh dari data sebaran panjang yang dihitung dengan rumus (Sparre \& Venema 1999):

$$
\begin{aligned}
& S_{L} \text { est }=\frac{1}{1+\operatorname{eks}\left(S_{1}-S_{2}{ }^{*} L\right)} \\
& \ln \left[\frac{1}{S_{L}}-1\right]=S_{1}-S_{2}{ }^{*} L \\
& L_{50 \%}=\frac{1}{S_{2}}
\end{aligned}
$$

dimana;

$\mathrm{S}_{\mathrm{L}}$ est $=$ kurva logistik; $\mathrm{S}_{1}=\mathrm{a} ; \mathrm{S}_{2}=\mathrm{b}$

$S_{1}$ dan $S_{2}=$ konstanta pada rumus kurva logistic

\section{Proporsi Ikan Tertangkap Hidup}

Pengamatan kondisi ikan hasil tangkapan dilakukan hanya terhadap ikan terubuk dengan kriteria sederhana; ikan berhasil naik ke atas dek dalam kondisi hidup atau mati. Selanjutnya ikan terubuk yang tertangkap dalam kondisi hidup, dilakukan pengamatan lanjutan terkait durasi daya hidupnya setelah berada dalam wadah penampungan selama trip penangkapan.

Proporsi ikan terubuk yang berhasil tertangkap dalam kondisi hidup dihitung dengan melakukan perbandingan dengan total ikan terubuk yang tertangkap selama uji coba penangkapan. Penghitungan proporsi tangkapan ikan terubuk yang tertangkap kondisi hidup menggunakan formula:

$\%$ Tangkapan terubuk hidup $=\frac{C h}{C h+C m} \times 100$ 
$\mathrm{Ch}=\mathrm{Ikan}$ terubuk yang tertangkap dalam kondisi hidup

$\mathrm{Cm}=\mathrm{Ikan}$ terubuk yang tertangkap dalam kondisi mati

\section{HASIL DAN BAHASAN}

Hasil

\section{Komposisi Hasil Tangkapan}

Selama kegiatan penelitian berhasil dilakukan sebanyak 57 operasi penangkapan (setting). Jenis ikan hasil tangkapan jaring insang dua lapis sangat bervariasi. Dua jenis ikan yang mendominasi hasil tangkapan jaring insang dua lapis adalah ikan biang- biang (Setipinna spp.) dan nomei (Harpodon spp.), sedang hasil tangkapan ikan terubuk selama uji coba penangkapan tercatat 96 ekor (Tabel 1).

\section{Laju Tangkap}

Hasil analisis terhadap hasil tangkapan jaring insang dua lapis memberikan nilai laju tangkap ikan terubuk berkisar antara 0,7 - 2,6 ekor/setting, nilai laju yang relatif tinggi terjadi pada Mei dan September 2016. Besaran nilai laju tangkap jaring insang dua lapis terhadap ikan nomei dan biang-biang selama kegiatan uji coba relatif lebih tinggi dibanding jenis ikan lainnya (Tabel 2).

Tabel 1. Komposisi jenis ikan hasil tangkapan selama selama uji coba penangkapan jaring insang dua lapis

Table 1. Catch composition of double gill net during trial fishing

\begin{tabular}{|c|c|c|c|}
\hline $\begin{array}{l}\text { Jenis Ikan/ } \\
\text { Fish Species }\end{array}$ & $\begin{array}{l}\text { Nama Inggris/ } \\
\text { English Name }\end{array}$ & $\begin{array}{l}\text { Hasil tangkapan } \\
\text { (ekor)/ Catch } \\
\text { (Numbers Of Fish) }\end{array}$ & $\begin{array}{c}\text { Persentase/ } \\
\text { Percentage (\%) }\end{array}$ \\
\hline Terubuk (Tenualosa macrura) & Terubok & 96 & 0,7 \\
\hline Nomei (Harpodon spp) & Bombay duck & 4065 & 28,0 \\
\hline Biang-biang (Setipinna spp) & $\begin{array}{l}\text { Shorthead hairfin } \\
\text { anchovy }\end{array}$ & 3667 & 25,3 \\
\hline Slanget (Clupeidae) & Hairback herring & 212 & 1,5 \\
\hline Tenggiri (Scomberomorus spp) & $\begin{array}{l}\text { Narrowbar Spanish } \\
\text { Mackerel }\end{array}$ & 69 & 0,5 \\
\hline Bulu ayam (Ilisha ilisha) & Chinese herring & 1437 & 9,9 \\
\hline Layur (Trichiurus spp) & Ribbon fish & 138 & 1,0 \\
\hline Cucut (Carcarhinus spp) & silky shark & 306 & 2,1 \\
\hline Bilis (Engraulididae) & $\begin{array}{l}\text { Blacksaddle } \\
\text { Herring }\end{array}$ & 663 & 4,6 \\
\hline Tiga waja (Johnius spp) & Bearded Croaker & 50 & 0,3 \\
\hline Tetengkek (Megalopsis cordyla) & Torpedo Scad & 462 & 3,2 \\
\hline Senangin (E. tetradactylum) & Splendid Threadfin & 10 & 0,1 \\
\hline Keting (Arius sp) & Sea catfishes & 26 & 0,2 \\
\hline Buntal (Diodon spp) & Milkspotted Puffer & 58 & 0,4 \\
\hline Bawal (Pampus argenteus) & Black Pomfret & 3211 & 22,2 \\
\hline Ikan lainnya & Other fish & 25 & 0,2 \\
\hline
\end{tabular}


Tabel 2. Laju tangkap (ekor/setting) jaring insang dua lapis menurut jenis ikan pada 2015-2016 Table 2. Catch rate (fish/setting) of double gill net based on species in 2015-2016

\begin{tabular}{|c|c|c|c|c|c|c|}
\hline \multirow{2}{*}{$\begin{array}{l}\text { Jenis Ikan/ } \\
\text { Fish } \\
\text { species }\end{array}$} & \multirow{2}{*}{$\begin{array}{l}\text { Nama Inggris/ } \\
\text { English name }\end{array}$} & \multicolumn{2}{|c|}{2015} & \multicolumn{3}{|c|}{2016} \\
\hline & & Mei & Nov & Mei & Sep & Okt \\
\hline Terubuk & Terobok & 2,0 & 0,6 & 2,6 & 2,4 & 0,7 \\
\hline Nomei & Bombay duck & 131,9 & 194,0 & 30,1 & 22,1 & 21,0 \\
\hline Biang-biang & Shorthead hairfin anchovy & 98,4 & 101,3 & 25,0 & 44,0 & 60,4 \\
\hline Selanget & Hairback herring & 1,4 & 4,7 & 7,9 & 4,5 & 1,3 \\
\hline Tenggiri & Narrowbar Spanish Mackerel & 2,6 & 1,2 & 1,9 & 0,5 & 0,4 \\
\hline Bulu ayam & Chinese herring & 15,5 & 11,6 & 11,4 & 28,1 & 49,4 \\
\hline Layur & Ribbon fish & 5,5 & 1,2 & 2,6 & 2,1 & 0,8 \\
\hline Cucut & silky shark & 2,6 & 3,0 & 9,5 & 5,5 & 6,8 \\
\hline Bilis & Blacksaddle Herring & 22,1 & 19,7 & 10,9 & 6,8 & 3,4 \\
\hline Bawal & Black Pomfret & & 0,1 & 10,0 & 2,2 & 2,7 \\
\hline Tetengkek & Torpedo Scad & & & 2,9 & 7,1 & 26,5 \\
\hline
\end{tabular}

\section{Posisi Tertangkap Ikan Pada Jaring}

Berdasarkan hasil pengamatan terhadap ikan yang tertangkap jaring insang dua lapis secara vertikal (berdasarkan tinggi jaring) terlihat bahwa ikan tertangkap pada seluruh bagian jaring; atas (dekat pelampung), tengah jaring dan bawah jaring (dekat pemberat) dengan persentase berbeda (Tabel 3). Bagian terbesar ikan terubuk (sekitar 64\%) tertangkap di bagian bawah jaring insang.

Tabel 3. Persentase ikan tertangkap berdasarkan posisi jaring insang dua lapis Table 3. Percentage of fishes caught by double gill net based on part of net position

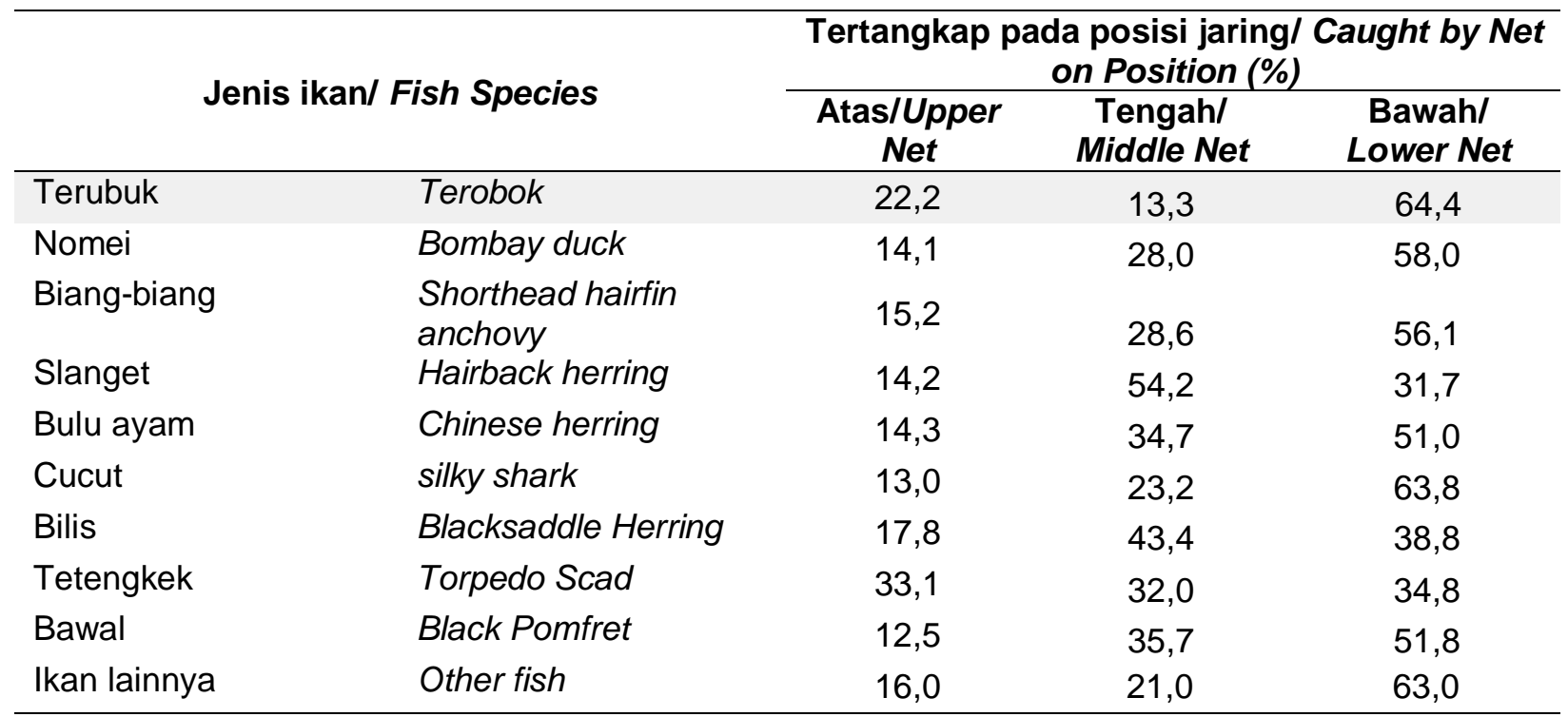

\section{Proporsi Ikan Terubuk Tertangkap Hidup}

Jumlah ikan terubuk yang tertangkap selama penelitian sebanyak 96 ekor. Dari jumlah tersebut sebanyak 26 ekor $(27,1 \%)$ ikan terubuk tertangkap dalam keadaan hidup dan selebihnya 70 ekor $(72,9$ $\%)$ dalam keadaan mati. Ciri-ciri ikan terubuk yang tertangkap dalam sehat dan terluka terlihat pada Gambar 4. Prosentase hasil tangkapan terubuk dalam kondisi hidup relatif sama dalam setiap trip ujicoba penangkapan, terkecuali pada trip bulan November 2015 mencapai 16,7\% (Tabel 4).

\section{Ukuran Ikan Hasil Tangkapan}

Hasil analisis terhadap $L_{50 \%}$ (pertama kali tertangkap $=L_{c}$ ) dari beberapa jenis ikan dominan yang tertangkap jaring insang dua lapis selama uji coba disajikan pada Tabel 5. 
Tabel 4. Persentase tangkapan ikan terubuk selama uji coba jaring dua lapis berdasarkan kondisi ikan selama uji coba penangkapan

Table 4. Catches pencentage of terubok during experimental fishing based on fish condition during trial fishing

\begin{tabular}{ccccccc}
\hline \multirow{2}{*}{$\begin{array}{c}\text { Kondisi/ } \\
\text { Condition }\end{array}$} & \multicolumn{2}{c}{$\mathbf{2 0 1 5}$} & & $\mathbf{2 0 1 6}$ & \multicolumn{2}{c}{$\begin{array}{c}\text { Rata2/ } \\
\text { average }\end{array}$} \\
\cline { 2 - 6 } & Mei & Nov & Mei & Sept & Okt & $\%$ \\
\cline { 2 - 6 } & $\%$ & $\%$ & $\%$ & $\%$ & $\%$ & $\%$ \\
\hline Hidup /Live & 28,6 & 16,7 & 28,6 & 27,5 & 25,0 & 27,1 \\
\hline Mati /Unlive & 71,4 & 83,3 & 71,4 & 72,5 & 75,0 & 72,9 \\
\hline
\end{tabular}

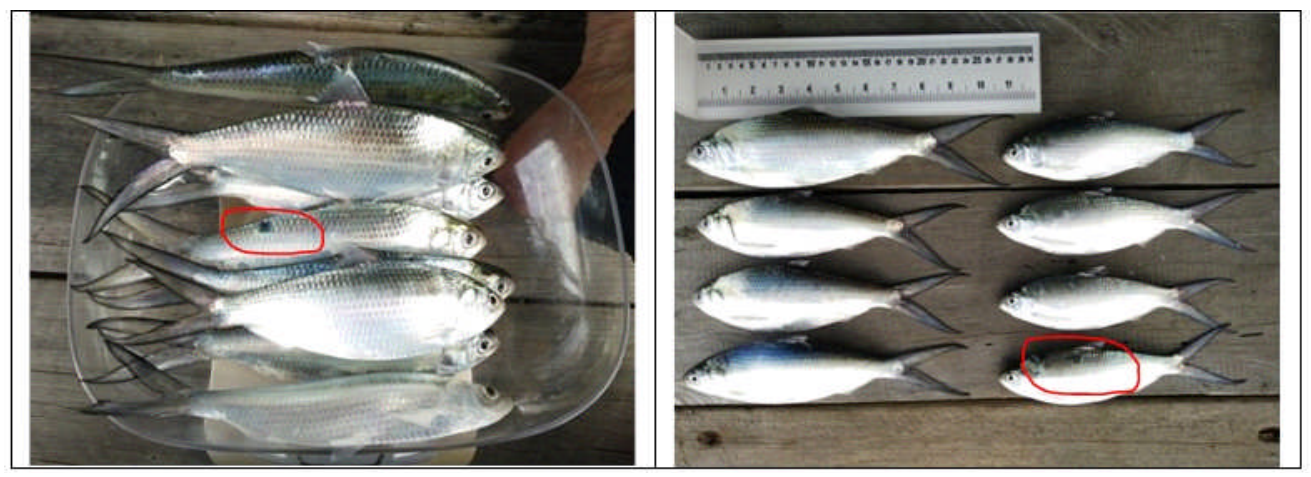

Gambar 4. Ikan terubuk yang tertangkap dengan kondisi sehat, dan yang terluka (tanda merah).

Figure 4. Terubok caught in healthy and the injured condition (marked in red).

Tabel 5. Ukuran pertama kali tertangkap hasil tangkapan ikan dominan dari jaring insang dua lapis Table 5. Length at first capture $\left(L_{c}\right)$ of dominant catch caught by double gillnet

\begin{tabular}{|c|c|c|}
\hline $\begin{array}{l}\text { Ukuran / } \\
\text { Size }\end{array}$ & $\begin{array}{l}\text { Terubuk/ } \\
\text { Terubok } \\
\text { FL (cm) }\end{array}$ & $\begin{array}{l}\text { Biang-biang/ } \\
\text { Shorthead } \\
\text { hairfin } \\
\text { anchovy } \\
\text { TL (cm) }\end{array}$ \\
\hline $\begin{array}{c}\text { Jumlah } \\
\text { sampel (n) }\end{array}$ & 58 & 344 \\
\hline $\mathrm{Lc}_{\mathrm{c}}(\mathrm{cm})$ & 17,43 & 13,83 \\
\hline \multicolumn{3}{|l|}{ Bahasan } \\
\hline \multicolumn{3}{|c|}{$\begin{array}{l}\text { Ikan terubuk termasuk jenis ikan pelagis dengan } \\
\text { karakteristik membentuk kawanan (schooling) saat } \\
\text { melakukan ruaya. Jenis makanan utamanya adalah } \\
\text { plankton dan detritus (Suwarso, 2016). Pada saat } \\
\text { melakukan pemijahan ikan terubuk melakukan ruaya } \\
\text { masuk ke wilayah perairan sungai. Kebiasaan ini } \\
\text { menjadi pertimbangan dalam upaya pemanfaatan/ } \\
\text { penangkapan ikan terubuk. }\end{array}$} \\
\hline
\end{tabular}

Pengetahuan tentang alat tangkap dan hasil tangkapannya adalah faktor penting dalam memahami proses penangkapan, pengembangan konstruksi dan rancangan alat penangkapan yang menuntut adanya keseimbangan dalam berbagai aspek (Syofyan et al., 2010). Jaring insang merupakan alat penangkap ikan

\section{Jenis ikan/ fish species}

$\begin{array}{cccc}\text { Nomei/ } & \text { Bilis/ } & \text { Slanget/ } & \text { Tetengkek/ } \\ \begin{array}{c}\text { Bombay } \\ \text { duck }\end{array} & \begin{array}{c}\text { Blacksaddle } \\ \text { Herring }\end{array} & \begin{array}{c}\text { Hairback } \\ \text { herring }\end{array} & \begin{array}{c}\text { Torpedo } \\ \text { Scad }\end{array}\end{array}$

TL (cm) TL (cm)

FL (cm)

FL (cm)

377

64

91

326

15,43

10,84

10,51

13,53

utama yang digunakan nelayan dalam menangkap ikan terubuk di Bengkalis. Prinsip pengoperasian jaring insang adalah menghadang arah gerakan ruaya ikan, sehingga menabrak, kemudian terjerat dan atau terpuntal jaring. Kebiasaan melakukan ruaya dalam bentuk kawanan dimanfaatkan dalam rancang bangun, konstruksi dan cara pengoperasiannya dalam penangkapan ikan terubuk. Jaring insang tergolong efektif digunakan untuk menangkap ikan terubuk, dalam kondisi ikan keadaan mati. Kontsruksi dan waktu rendam (soaking time) alat penangkap ikan jaring insang diduga memberikan pengaruh besar terhadap kondisi ikan hasil tangkapan dalam kondisi mati.

Jaring insang dua lapis merupakan pengembangan dari jaring insang yang selama ini digunakan untuk 
menangkap ikan terubuk. Jaring insang dua lapis terdiri dari 2 lapis jaring dimana setiap lapis jaring memiliki fungsi berbeda dalam pengoperasiannya. Lapis jaring dengan ukuran mata jaring lebih besar (outer) berfungsi sebagai frame, sedang lapis jaring berukuran mata kecil (inner) berfungsi untuk terbentuknya kantong. Upaya menangkap ikan terubuk dalam keadaan hidup membutuhkan desain dan konstruksi penangkapan dengan menggunakan alat penangkap ikan modifikasi jaring insang.

Umumnya penangkapan ikan terubuk dilakukan pada saat memijah. Sistem penangkapan seperti ini secara langsung akan mengancam kelangsungan dan kelestarian ikan terubuk, karena akan menjadi sasaran tangkap adalah induk -induk ikan yang akan bertelur dan beruaya untuk memijah. Kondisi tertangkapnya ikan terubuk yang banyak didominasi oleh ikan jantan dibandingkan betina juga dialami oleh penelitian sebelumnya, hal ini disebabkan oleh sifat perubahan kelamin (sex reversal) dari ikan terubuk. Sementara ikan terubuk betina yang tertangkap merupakan ikan yang tadinya berkelamin jantan. Dilihat dari banyaknya tertangkap pada bulan gelap dan malam hari, disebabkan oleh ikan terubuk yang beruaya tidak dapat melihat mata jaring sehingga tidak dapat menghindar (Purwanto et al, 2007). Kondisi tertangkapnya ikan terubuk yang banyak didominasi ikan betina dibandingkan ikan jantan juga dialami oleh penelitian sebelumnya (Sihotang, 1991: Ahmad et al., 1995; Blaber et al., 1999; Merta, et al., 1999 dan Efizon, et al., 2012). Hal ini disebabkan oleh proses pemijahan yang terjadi setiap bulannya, sehingga lahirnya generasi-generasi baru menuju dewasa lebih banyak.

Waktu (kecepatan) dalam pengoperasian jaring dua lapis sangat dipengaruhi oleh kondisi perairan (arus, gelombang) dan banyaknya ikan selain ikan terubuk yang ikut tertangkap. Ikan yang tertangkap tidak hanya ikan terubuk, namun banyak ikan-ikan lainnya yang ikut tertangkap, sehingga waktu proses pengangkatan jaring menjadi lama terutama saat melepaskan ikan yang tertangkap.

Ukuran panjang cagak (FL) ikan terubuk yang tertangkap berkisar antara 13,5-29,5 cm dengan bobot berkisar antara 32 - 424 gram, diantaranya sebanyak 4 ekor dalam kondisi matang gonad (TKG IV).

Untuk meningkatkan kelulusan hidup ikan terubuk yang tertangkap jaring dua lapis adalah penentuan waktu rendam jaring (soaking time) dan proses pengangkatan jaring (hauling) yang tepat, dengan mengupayakan waktu relatif tidak lama sehingga ikan terubuk yang tertangkap oleh jaring diharapkan tidak berlama-lama berada di kolom air dalam kondisi terperangkap.

Upaya lain untuk menjaga agar hasil tangkapan terubuk tetap bertahan hidup selama operasi penangkapan, diperlukan penanganan pasca penangkapan selama di atas kapal sampai didaratkan di pangkalan. Diperlukan wadah penampungan yang memadai dilengkapi dengan sistem aerasi dan mengkondisikan ikan terubuk tidak terlampau aktif. Beberapa ikan terubuk hidup yang tersimpan dalam penampungan (sementara) mampu bertahan hidup sampai $>24$ jam.

Selama pelaksanaan kegiatan ujicoba (experimental fishing), perolehan hasil tangkapan ikan terubuk sangat sedikit. Hal ini diduga terkait dengan potensi atau populasi ikan terubuk yang sudah menurun pada tahun terakhir ini sehingga ikan yang beruaya membentuk kawanan (schooling) relatif kecil. Hal ini dipertegas bahwa keberadaan ikan terubuk di perairan Bengkalis pada periode terang bulan (fullmoon), sebaran kelimpahan pias (terubuk muda) dan terubuk pada kedalaman permukaan $(10-20 \mathrm{~m})$ di Selat Bengkalis dengan kelimpahan yang relatif rendah ratarata hanya 1 - 5 ekor/1000m ${ }^{3}$ (Anonymous, 2014). Untuk memperbaiki performa alat tangkap (jaring dua lapis dan pukat terubuk), meningkatkan efektivitas kinerja alat tangkap saat dioperasikan dan meningkatkan peluang keberhasilan alat tangkap dalam menangkap ikan terubuk, dilakukan perbaikan (perubahan - perubahan) pada bagian tertentu. Perbaikan performance jaring dua lapis dilakukan dengan cara menambah jumlah tinting (pieces) dari 10 tinting menjadi 22 tinting, perubahan penggunaan mata jaring pada jaring lapis dalam (inner net) yang lebih besar dari $1 \frac{1}{4}$ inci menjadi $1 \frac{1}{2}$ inci sehingga dapat meminimalisir tertangkapnya ikan - ikan kecil (jenis udang). Perubahan dimensi jaring juga dilakukan dengan cara pengurangi ukuran lebar jaring terpasang yaitu dari lebar jaring 8,9 m menjadi 5,3 m. Dengan demikian, jaring dua lapis saat dioperasikan menjadi lebih efektif dan tidak mengurangi peluang untuk dapat menangkap ikan terubuk.

Jaring dua lapis dan dioperasikan di lapisan perairan yang mana diduga merupakan lintasan pergerakan (ruaya) ikan terubuk dan merupakan waktu ikan terubuk melintasi di daerah pengoperasian, yaitu pada periode bulan terang ( full moon) dan bulan mati (dark moon) khususnya di perairan Kabupaten Bengkalis. Aktivitas penangkapan terubuk dapat dilakukan setiap periode bulan gelap dan periode terang bulan dengan waktu yang relatif sempit, masing-masing berlangsung $3-5$ hari. Dilihat dari 
waktu penangkapan pada setiap bulannya ikan terubuk banyak tertangkap pada waktu bulan gelap (tanggal 28, 29, 30 dan 1 Hari Bulan Arab) dibandingkan waktu penangkapan pada bulan terang (13, 14, 15 dan 16 Hari Bulan Arab), jika dilihat dari waktu siang dan malam, ikan terubuk lebih banyak tertangkap pada waktu malam hari (Efizon et. al., 2012)

Penangkapan pada musim barat (DesemberMaret) hanya berlangsung 2 - 3 hari setiap periode penangkapan akibat cuaca dan arus laut yang kurang baik (Merta et al., 1997). Berbagai hasil penelitian bahwa fase bulan sangat berpengaruh terhadap hasil tangkapan, dapat menentukan waktu terbaik untuk penangkapan ikan, fase bulan akan mempengaruhi kondisi pasang surut paras muka laut yang pada akhirnya akan mempengaruhi ketersediaan makanan khususnya plankton. Dengan fase bulan juga menjadi indikator penting sebagai penentu waktu reproduksi, dalam hal ini indikator fase bulan akan menentukan waktu pemijahan (Kordi 1997; Dewar, et al., 2008; Babcock et al. 1986; Wiyono \& Mahiswara, 2013).

Alat tangkap terubuk hasil inovasi dirancang dengan penggunaan material dan cara pengoperasian dengan mempertimbangkan tingkah laku dan kebiasaan hidup, ukuran (morfometrik) ikan terubuk yang akan ditangkap terutama ukuran panjang cagak (fork length) dan keliling operculum (Gird Opercolum)) (Prado, 1990). Pilihan bahan jaring PA monofilament yang halus agar tidak menyebabkan luka, ukuran mata jaring yang memungkinkan ikan tidak terjerat, perakitan jaring yang mampu menjangkau kolom perairan jalur pergerakan ikan terubuk, memungkinkan terbentuknya kantong serta penentuan waktu rendam jaring (soaking time) yang tepat sehingga tidak menyebabkan kematian ikan yang merupakan syarat teknis utama inovasi alat tangkap jaring terubuk. Terjadinya luka pada tubuh ikan akan mempengaruhi pada respons stress dan mortalitas pada ikan akan yang tertangkap jaring (Purbayanto et al., 2010).

Jaring dua lapis tergolong kelompok alat tangkap jaring insang (gill net). Konstruksi alat tangkap terdiri atas dua lembaran jaring. Untuk tujuan penangkapan ikan terubuk kedua lembar jaring memiliki ukuran mata jaring yang berbeda. Prinsip tertangkapnya ikan terubuk oleh jaring dua lapis adalah; ikan terubuk yang menabrak lembar jaring berukuran mata kecil (1,5 inci) secara tidak terjerat akan tertahan oleh lembar jaring berukuran mata besar (7,0 inci), sehingga membentuk kantong. Pembentukan kantong terjadi apabila ikan terubuk yang terhadang menabrak jaring berukuran mata kecil, dan tidak terjerat, selanjutnya menabrak jaring berukuran mata besar dan tertahan.
Kantong jaring terbentuk dengan memberikan nilai pengerutan (shrinkage) jaring mata kecil yang tinggi $(60 \%)$ dan pengerutan jaring mata besar yang rendah (30\%). Dengan nilai pengerutan tersebut di dalam air performansi jaring mata besar lebih tegang dibandingkan mata kecil. Penentuan kombinasi ukuran mata jaring (mesh size) dan nilai pengerutan (shortening) jaring insang lingkar (encircling gill net) yang tepat, dapat mempengaruhi keberhasilan penangkapan (Johannes et al., 2011). Secara parsial ukuran mata jaring dan nilai pengerutan jaring insang permukaan berpengaruh terhadap hasil tangkapan ikan layang, nilai kerutan 45\% lebih efisien dari nilai kerutan 30\% (Tawari, 2011). Pada penelitian yang berbeda, diterangkan bahwa perbedaan ukuran mata jaring gill net yang kecil hanya sedikit berpengaruh terhadap jumlah tangkapan total dan ukuran rata-rata panjang ikan kembung lelaki ( $R$. kanagurta) (Tambunan, et.al.,2010).

Konstruksi dan desain alat tangkap terubuk disesuaikan dengan tingkah laku, ruaya, habitat dan swimming layer dari ikan terubuk tersebut. Berdasarkan cara tertangkapnya ikan terubuk dengan jaring dua lapis, diperoleh bahwa ikan terubuk yang tertangkap tersebar dan didominasi berada di bagian bawah jaring (dekat pemberat) mencapai 64,4\%, sementara yang tertangkap di bagian atas jaring (dekat pelampung) diperoleh $22,2 \%$ dan yang tertangkap di bagian tengah jaring sebanyak 13,3\%. Berdasarkan sebaran posisi ikan terubuk yang tertangkap pada jaring dua lapis mengindikasikan bahwa keberadaan potensi atau populasi ikan terubuk yang beruaya membentuk kelompok (schooling) yang relatif kecil dan keberadaan ruaya ikan terubuk di area uji coba penangkapan cenderung berenang di lapisan bawah perairan pada kedalaman lebih dari $10 \mathrm{~m}$. Ikan terubuk muda (pias) cenderung berenang di kedalaman permukaan ketika bermigrasi ke selat Malaka. Sementara terubuk cenderung berenang pada kedalaman yang lebih dalam saat migrasi ke Selat Malaka (Anonymous, 2014).

Terkait dengan area tangkap (catchable area) pada kolom perairan yang dapat dijangkau oleh jaring dua lapis (sebanyak 22 tinting, dengan panjang 32 m/tinting) relatif luas dan mampu menjangkau kolom perairan jalur pergerakan ikan. Sehingga dengan memanfaatkan jaring dua lapis secara tertib dalam hal rancang bangun, konstruksi (termasuk pemilihan bahan), cara pengoperasian serta penanganan pasca penangkapan, berpeluang memperoleh ikan terubuk (kriteria pias dan terubuk) baik kuantitas maupun kualitas hasil tangkapan kondisi hidup, kondisi prima dan tidak melukai. 
Dari aspek teknis jaring dua lapis dirancang bangun dan dikonstruksi sederhana sehingga mudah dibuat dan dioperasikan. Konstruksi jaring memungkinkan penampilannya di dalam air membentuk kantong ketika ikan menabrak. Bangun kantong pada jaring dua lapis diharapkan ikan terubuk yang tertangkap tetap hidup selama di dalam air. Konstruksi jaring dua lapis dirancang untuk menangkap ikan terubuk hidup untuk keperluan upaya budidaya, sehingga target penangkapan ukuran ikan relatif besar. Ikan terubuk ukuran kecil yang tertangkap dalam keadaan hidup, tidak cedera dan dapat dilepaskan kembali. Selanjutnya tantangan yang dihadapi adalah, upaya meningkatkan kelulusan hidup ikan terubuk yang tertangkap.

\section{KESIMPULAN}

Rancang bangun jaring dua lapis berbahan senar monofilament dengan ukuran mata jaring inner net 1,5 inci dan outter net 7,0 inci dengan pengerutan (shrinkage) masing-masing 60\% dan 30\%, serta panjang satu tinting jaring 32 meter dan lebar 5,3 meter dapat digunakan untuk menangkap ikan terubuk hidup. Proses penangkapan jaring dua lapis cukup efektif dan berpeluang menangkap ikan terubuk (kriteria pias dan terubuk) dalam kondisi hidup dan tidak terluka sehingga ikan hasil tangkapan dapat memenuhi kebutuhan budidaya. Efektivitas jaring dua lapis untuk menangkap ikan terubuk dalam kondisi hidup perlu memperhatikan waktu rendam kecepetan penarikan (hauling) dan panjang jaring yang dioperasikan. Sebanyak 30\% hasil tangkapan ikan terubuk tertangap dalam keadaan hidup dan tidak cedera. Sebagian hasil tangkapan terubuk mampu bertahan hidup hingga $>24$ jam setelah didaratkan.

\section{PERSANTUNAN}

Tulisan ini merupakan kontribusi dari kegiatan riset Inovasi Alat Tangkap Ikan Terubuk Untuk Menunjang Upaya Konservasi T.A. 2015 - 2016, di Balai Penelitian Perikanan Laut Muara Baru, Jakarta. Diucapkan terima kasih kepada teknisi dan nelayan yang membantu uji coba di lapangan.

\section{DAFTAR PUSTAKA}

Ahmad, M. (1974). Perkembangan usaha perikanan di Tanjung Medang Kecamatan Rupat (p. 20). Warta Universitas Riau, Pekanbaru.

Ahmad, M. (1975). Tentang terubuk (Clupea sp) di Perairan Tanjung Medang, Kecamatan Rupat. Berkala Terubuk I. (1), 2 - 9.
Ahmad, M., Dahril T., \& Efizon, D. (1995). Ekologi reproduksi ikan terubuk (Alosa toli) di perairan Bengkalis, Riau. Jurnal Perikanan dan Kelautan. 1, 2-19.

Anonymous. (2014). Laporan pengkajian stok bagi pengelolaan dan konservasi sumberdaya ikan di Perairan Kabupaten Bengkalis. Kerjasama Penelitian antara Balai Penelitian Perikanan Laut, Balitbang Kelautan dan Perikanan. Kementerian Kelautan dan Perikanan dengan Dinas Kelautan dan Perikanan Kabupaten Bengkalis 2014. p.73.

Babcock, R. C., Bull, G. D., Harrison, P. L., Heyward, A. J., Oliver, J. K., Wallace, C. C., \& Willis, B.L. (1986). Synchronous spawnings of 105 ScIrecatinian Coral Species on The Great Barrier Reef. Mar Biol. 90, 379-394.

Baskoro, M. S. (2006). Alat penangkap ikan berwawasan lingkungan. Kumpulan Pemikiran Tentang Teknologi Perikanan Tangkap yang Bertanggung jawab. Departemen Pemanfaatan Sumberdaya Perikanan. FPIK. IPB. p. 7-13.

Blaber, S. J. M., Milton, D. A., Brewer, D. T., \& Salini, J. P. (1991). The shads (Genus Tenualosa) of Troficalnasia: An Overview of Their Biology, Status and Fisheries (p. 9-17). Internasinal Terubok Conference. Proceedings of the International Terubok Conference Sarawak, Malaysia.

Blaber, S. J. M., Milton, D. A., Pang, J., Wong, P., Ong Boon - Teck, Nyigo L., \& Lubim, D. (1996). The life history of the tropical shad Tenualosa toli from Sarawak: first evidence of protandry in the Clupeiformes?. Environmental Biology of Fishes. 46, 225-242.

Blaber, S. J. M. (1998). Reproductive ecologi and life history in Indonesia. Presented at Second Coordination Meeting on Terubuk Fishery. Pekanbaru 1998.

Blaber, S. J. M., Brewer, D. T., Milton, D. A., Merta, I. G. S., Efizon, D., Fry G., \& Van der Velde, T. (1999). The life history of the protandrous tropical sahad Tenualosa macrura (Alosinae: Clupeidae): fishery implications. Estuarine Coastal and Shelf Science. 49, 689-701.

Carpenter, K. E. \& Niem, V. H. (1999). FAO species identification guide for fishery purpose. The Living Marine Resources of the Western Central Pacific. Vol 3 Batoid Feshes, Chimaeras and Bony Fishes Part 1. FAO of The United Nation 1397-2068. 
De Bruin G. H. P., Russel, B. C., \& Bogusch, A. (1994). Fao species identification field guide for fishery purposes. The Marine fishery Resources of Srilanka. Food and Agriculture Organization of the Unite Nation Rome. p. 400.

Dewar, H., Mous, P., Domeier, M., Muljadi, A., Pet, J., \& Whitty, J. (2008). Movements and site fidelity of Giant Manta Ray, Manta birostris, in The Komodo Marine Park, Indonesia. Marine Biology, 155, $121-133$.

Efizon, D., Otong, S. D., Yayat, D., \& Bachrulhajat, K. (2012). Kelimpahan populasi dan tingkat eksploitasi ikan terubuk (Tenualosa Macrura) di perairan Bengkalis, Riau. Berkala Perikanan Terubuk, 40(1), 52-65.

Johannes, S., Matakupan, H., \& Matrutty, D. D. P. (2011). Efisiensi penangkapan jaring insang lingkar dengan ukuran mata jaring dan nilai pengerutan yang berbeda di perairan Pesisir Negeri Waai. Prosiding Seminar Nasional Pengembangan Pulau Pulau Kecil Dari Aspek Perikanan Kelautan dan Pertanian. Institut pertanian Bogor dan Persatuan Mahasiswa Maluku (Permama) Bogor. Direktorat Kemahasiswaan, Institut Pertanian bogor. p. 256262.

Kordi, M. G. H. (1997). Budidaya kepiting dan ikan bandeng di tambak sistem polikultur (p. 31-40). Semarang. Dahara Prize.

Merta, I. G. S., Suwarso., Karsono, W., Girsang, E. S. \& Suprapto. (1999). Status populasi dan bioekologi ikan terubuk, Tenualosa macrura (Clupeidae) di Provinsi Riau. J. lit. Perikan. Ind. 5 (3), 15-29.

Merta, I. G. S., Suwarso \& Atmaja, S. B. (1997). Preliminary study on catch fluctuation oatterns of "Terubuk", Tenualosa macrura, fishery in Bengkalis Waters, Riau Province. Presented at Firs Coordination Meeting on Terubuk Fishery. Pekanbaru, 23-24 July 1997.

Prado, J. (1990). Fisherma's Workbook. FAO of the United Nation. By Fishing News Books. Okford 1990.
Purbayanto, A., Riyanto, M., \& Fitri, A. D. P. (2010). Fisiologi dan tingkah laku ikan pada perikanan tangkap (p. 208). Fakultas Perikanan dan IImu Kelautan IPB.IPB Press. Bogor.

Purwanto, E., Yani, A. H., \& Efizon, D. (2007). Study fisheries fish Terubuk (Tenualosa macrura) In Waters Bengkalis Riau. Fisheries and Marine Science Faculty. Universitas Riau.

Sihotang, C. (1991). Studi tentang Bio-ekologi lkan Terubuk (Clupea toli) di Perairan Riau (p. 36). Proyek Pengembangan Pendidikan Ilmu Kelautan Fakultas Perikanan Universitas Riau, Pekanbaru.

Sparre, P \& Venema, S. C. (1999). Introduksi pengkajian stok ikan tropis buku - I, manual (Edisi Terjemahan). Kerjasama Organisasi Pangan, Perserikatan Bangsa - Bangsa dengan Pusat Penelitian dan Pengembangan Perikanan, Badan Penelitian dan Pengembangan Pertanian. Jakarta.

Subani, W., \& Barus, H. R. (1989). Alat penangkap ikan dan udang laut di Indonesia. Jurnal. Penelitian Perikanan Laut Edisi Khusus 1988/1989. (50), 248.

Suwarso. (2016). Sumber daya ikan terubuk (Tenualosa Sp.) di perairan pantai Pemangkat, Kalimantan Barat. p. 12 (Tidak diterbitkan).

Suwarso \& Merta, I. G. S. (1997). Kelimpahan populasi ikan terubuk, Tenualosa macrura (Clupeidae) dan dugaan produksinya di perairan estuarin sekitar Bengkalis (Riau). Simposium Perikanan Indonesia II, Ujung Pandang, 23-24 September 1997. 99-103.

Syofyan, I., Syaifuddin. \& Cendana, F. (2010). Studi komparatif alat tangkap jaring insang hanyut (drift gillnet) bawal tahun 1999 dengan tahun 2007 di Desa Meskom Kecamatan Bengkalis Kabupaten Bengkalis Propinsi Riau. Jurnal Perikanan dan Kelautan. 15(1), 62-70.

Tambunan S. B. S., Fauziyah., \& Agustriani, F. (2010). Selektivitas drift gillnet pada ikan kembung lelaki (Rastrelliger kanagurta) di perairan Belawan Pantai Timur Sumatera Utara Provinsi Sumatera Utara. Maspari Journal. 1 (1), 63-68. 
Tawari R. H. S. (2011). Efisiensi jaring insang permukaan terhadap hasil tangkapan ikan layang (Decapterus macarelus) di Teluk Kayeli. Jurnal Amanisal PSP FPIK Unpatti-Ambon. 2(2), 32-39.
Wiyono, E.S. \& Mahiswara. (2013). Pengaruh fase bulan terhadap hasil tangkapan purse seine di Bone, Sulawesi Selatan. Buletin PSP. Departemen Sumberdaya Ikan, FPIK-IPB. 21(3). 